\title{
LARVICIDAL EFFICIENCY OF SOME INORGANIC COMPOUNDS AND PLANT EXTRACTS AGAINST THE HOUSE FLY
}

\author{
J. WILLOMITZER and J. TOMÁNEK \\ Veterinary Research Institute, 62132 Brno
}

Received fuly 28, 1980

\begin{abstract}
Willomitzer J., J. Tománek: Larvicidal Efficiency of Some Inorganic Compounds and Plant Extracts against the House Fly. Acta vet. Brno, 50, 1981 : 105-112.

Copper sulphate, iron sulphate, magnesium sulphate, sodium tetraborate, aqueous extracts of great nettle (Urtica dioica), horse-tail (Equisetum arvense), mugwort (Artemisia vulgaris) and an alcoholic extract of garlic (Alium sativum) were tested for efficiency against house fly (Musca domestica) larvae under laboratory conditions. Larvicidal efficiency was shown by 4 per cent magnesium sulphate, horse-tail decoctions, mugwort extract and particularly by 4 to 12 per cent sodium tetraborate (used as a spray) and hydrated sodium tetraborate.

Copper sulphate, iron sulphate, magnesium sulphate, sodium tetraborate, Urtica dioica, Equisetum arvense, Artemisia vulgaris, Alium sativum.
\end{abstract}

Insect control is a problem of increasing magnitude in intensive animal production systems where insects are not only a nuisance to animals and animal attendants, but are also involved in the transfer of a number of infectious diseases. This has led to frequent use of insecticides, many of which are injurious to health.

Recently efforts have been made all over the world to replace toxic inseeticides by natural or synthetic substances that are not injurious to higher warm-blooded organisms including man and have a satisfactory insecticidal efficiency. The rationale behind this approach is concern for the protection of the environment against growing pollution.

Experience from horticultural practice (Novák 1978, Rolínková 1979) has shown that extracts of some plants (e. g. horse-tail, nettle and garlic) have insecticidal effects. Of particular importance is the recent observation of Schneider and Groth (1976) who found that sodium tetraborate was effective against Musca domestica larvae.

The present study was designed to test larvicidal efficiency of some inorganic compounds and plant extracts against Musca domestica larvae under laboratory conditions.

\section{Materials and Methods}

House flies (Musca domestica) were reared in 4 1-bottles by placing of at least 10 imagoes (males and females in approximately equal numbers) into each bottle, the bottom of which was previously filled with $125 \mathrm{~g}$ wetted wheat bran and overlaid with $40 \mathrm{~g}$ bovine faeces. An ample supply of honey diluted 1:10 with water was added as adult food. The necks of the bottles were closed with monofilament nets by means of rubber bands (Fig. 1). The contents of the bottles were wetted daily with water. The temperature of the room where the bottles were kept ranged between 23 and $28^{\circ} \mathrm{C}$ in summer months and was maintained at 27 to $29{ }^{\circ} \mathrm{C}$ in winter months by means of a heat lamp. The development of domestic flies at this temperature and sufficient relative humidity took 4 to 13 days (mean $=6.7$ days) from oviposition to emergence of larvae, 4 to days (mean $=$ $=8.8$ days) from larval stage to puparium and 4 to 14 days (mean $=7.8$ days) from puparium to imago. Thus the development of domestic flies was completed in 12 to 37 days (mean $=21.1$ days). The rate of emergence of imagoes from puparia was 41.5 per cent.

The compounds tested for larvicidal efficiency were copper sulphate $\left(\mathrm{CuSO}_{4}\right)$, iron sulphate $\left.(\mathrm{FeSO})_{4}\right)$, magnesium sulphate $\left(\mathrm{MgSO}_{4}\right)$ and sodium tetraborate $\left(\mathrm{Na}_{2} \mathrm{~B}_{4} \mathrm{O}_{7}\right)$. These compounds 
were weighed in crystalline forms as hydrates .Sodium tetraborate was first used in aqueous solution as a spray and later in the solid form mixed with wheat bran. Extracts or decoctions were prepared from the following plants: great nettle, horse-tail, mugwort and garlic.

Great nettle (Urtica dioica) extracts were prepared in two forms of differing strength. The weaker extract was prepared by immersing $0.5 \mathrm{~kg}$ fresh great nettle in 81 water and allowing it to macerate for 3 days. The stronger extract was prepared by immersing $0.5 \mathrm{~kg}$ fresh great nettle in 31 water and allowing it to macerate for 5 days. The two macerates were strained through a sieve and the resultant extracts were used as sprays.

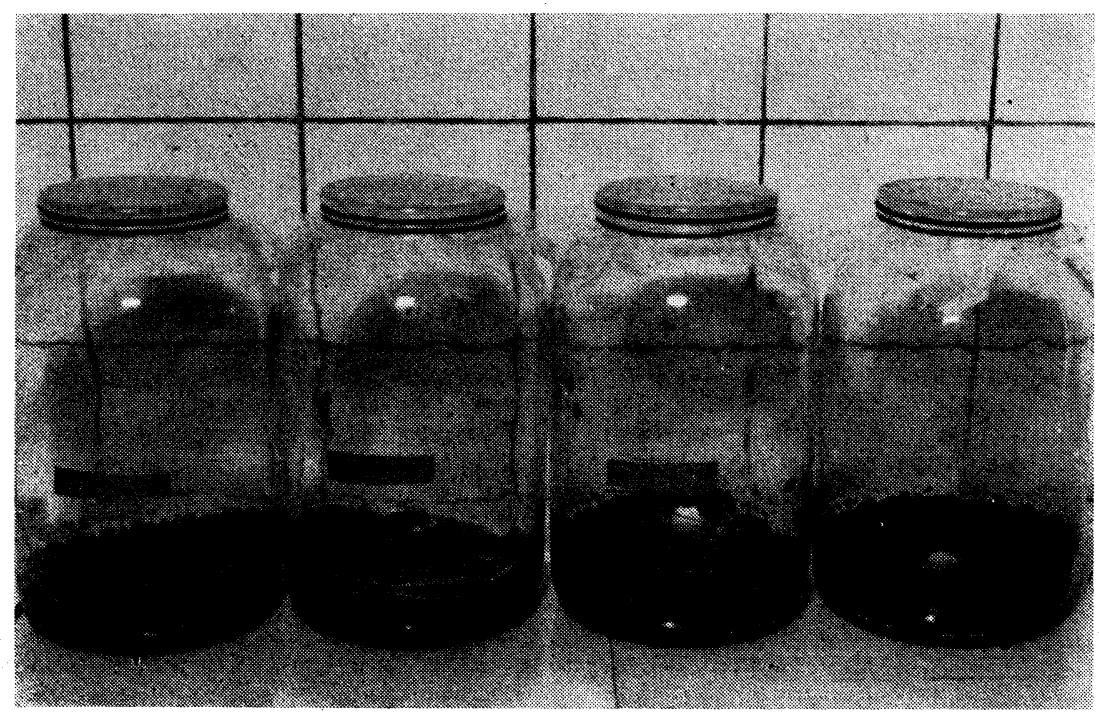

Fig. 1.

Rearing of domestic flies in experimental bottles

Horse-tail (Equisetum arvense) decoctions were prepared in two forms of differing strength. The weaker decoction was prepared by boiling $13 \mathrm{~g}$ dried horse-tail in $500 \mathrm{ml}$ water for 5 minutes. The stronger decoction was prepared by boiling $50 \mathrm{~g}$ fresh horse-tail in $400 \mathrm{ml}$ water for 5 minutes. The two decoctions were allowed to cool and then used as sprays.

Mugwort (Artemisia vulgaris) extracts were also prepared in two forms of differing strength. The weaker and stronger extracts were obtained by macerating 200 and $350 \mathrm{~g}$ mugwort in 1000 and $1300 \mathrm{ml}$ water for 7 and 3 days, respectively. The resulting extracts were used as sprays.

Garlic (Alium sativum) alcoholic extracts were prepared by immersing $30 \mathrm{~g}$ of finely cut garlic cloves in $100 \mathrm{ml}$ of 96 per cent ethyl alcohol $\left(\mathrm{C}_{2} \mathrm{H}_{5} \mathrm{OH}\right)$ and allowing it to macerate for one week with daily agitation. The resultant extract was used as a spray. Ethyl alcohol itself was also tested for possible larvicidal action.

The larvicidal effects of the aforementioned substances and extracts were evaluated on the basis of daily observations for larval and imago mortality and for emergence of imagoes in the treated and control bottles. The fact that imagoes die after a certain period of time in both treated and control bottles was taken into consideration.

Sodium tetraborate which showed relatively good larvicidal effects was tested for toxicity in guinea-pigs and calves before being used under semi-operational conditions. Five guinea-pigs were administered 8 per cent sodium tetraborate in oral doses of $1 \mathrm{ml}$ per animal and in the form of spray to the whole body. The two applications were administered on alternate days. Similarly, two calves, 75 and $110 \mathrm{~kg}$ in body mass, were given 8 per cent sodium tetraborate in oral doses of $40 \mathrm{ml}$ per animal and in the form of spray to the whole body an alternate days.

To assess the effects of sodium tetraborate under semi-operational conditions, two biotopes $(1 \times 1 \mathrm{~m})$ with cattle man 1 re $0.25 \mathrm{~m}$ deep were set in a barn and flies were allowed to lay eggs 
there for 4 days. As soon as larvae were observed, one biotope was sprayed with 8 per cent sodium tetraborate and the other was left untreated to serve as a control. A tent-like construction covered with gauze was then erected over each biotope to capture the imagoes. The two biotopes were observed for emergence of imagoes and their development.

Residual effects of 8 per cent sodium tetraborate were investigated in the following way: Groups of 10 imagoes each were placed in rearing bottles for egg deposition. As soon as larvae were observed, the bottles were sprayed with 8 per cent sodium tetraborate and control bottles were left untreated. As soon as imagoes and larvae in the treated bottles were killed, other groups of ten imagoes each were added to these bottles which received no further treatment and were observed for residual effects of sodium tetraborate.

\section{Results}

Of the sulphates tested for larvicidal efficiency as sprays (Table 1, Experiments 1-4) 4 per cent magnesium sulphate proved effective. In the treated bottle the development of flies was stopped before puparium stage, whereas eggs laid by females in the control bottle developed into puparia from which a new generation of imagoes emerged.

Of the plant extracts and decoctions tested the stronger of the two horse-tail (Equisetum arvense) decoctions proved effective when used as a spray at the rate of $50 \mathrm{ml}$ for 5 days. In the treated bottle the development of flies was stopped before puparium stage, whereas 20 imagoes emerged in the control bottle (Table 1, Experiment 9).

A similar result was obtained with the stronger of the two mugwort (Artemisia vulgaris) extracts used as a spray in a single $50 \mathrm{ml}$ dose. Larval development was stopped in the treated bottle, whereas 50 imagoes emerged in the control bottle (Table 1, Experiment 11).

Alcoholic extracts of garlic (Alium sativum) did not affect the development of flies even at concentrations as high as 50 per cent (Table 2, Experiments 1-7).

The best larvicidal effect was shown by sodium tetraborate (Table 3) administered in the form of spray on one or several occasions (Experiments 2, 4, 5, 6

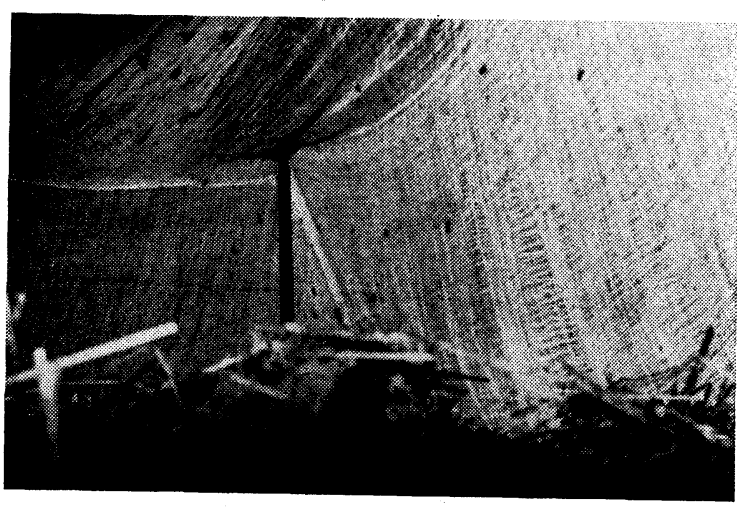

Fig. 2.

Imagoes in the treated biotope

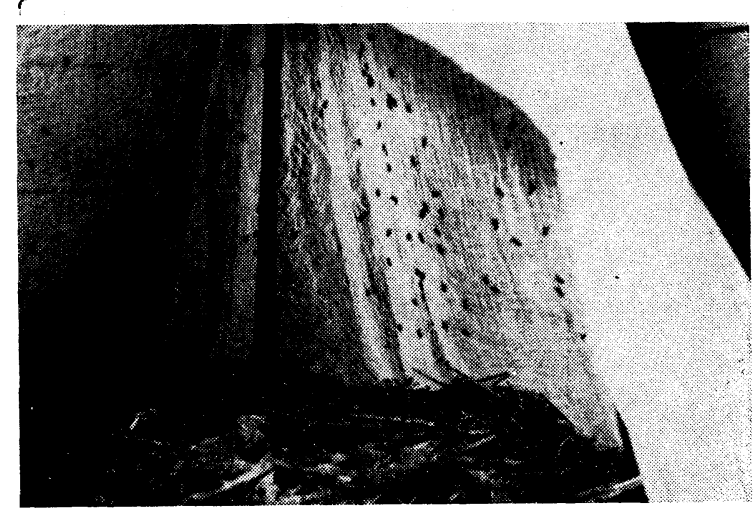

Fig. 3.

Imagoes in the control biotope 


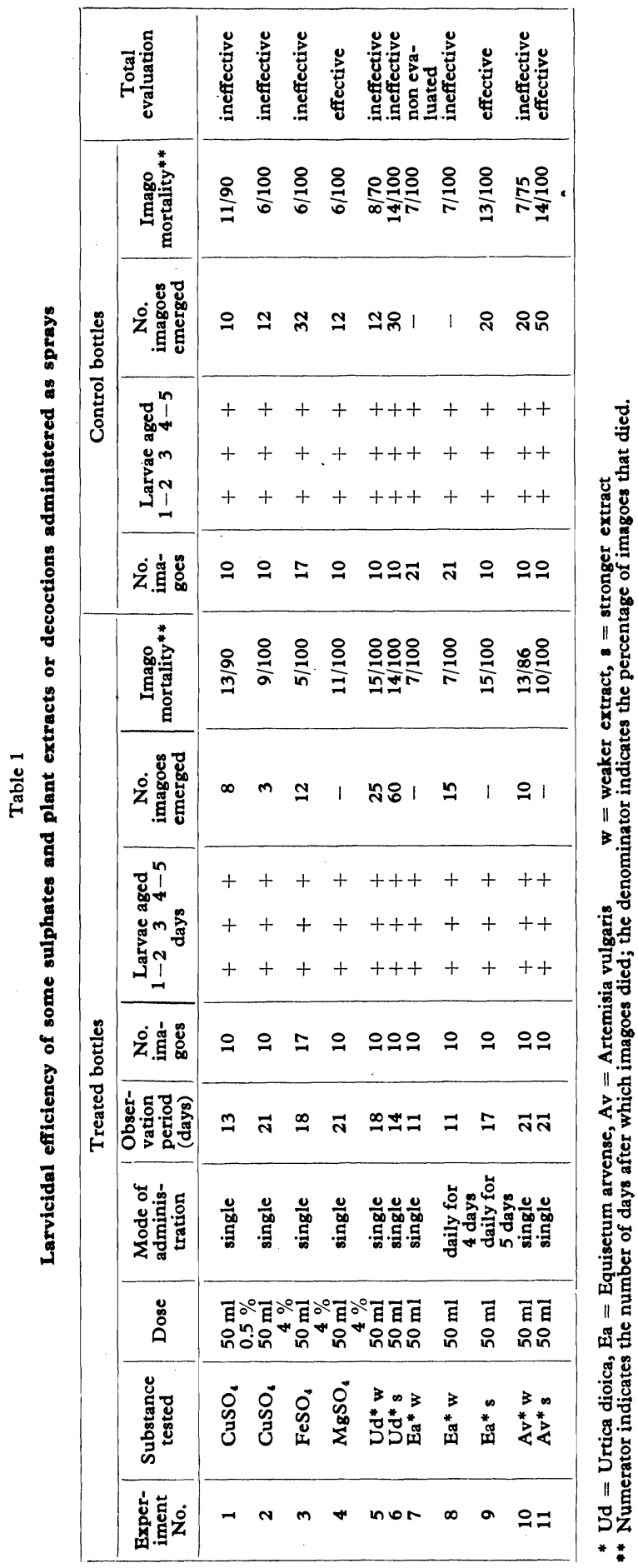




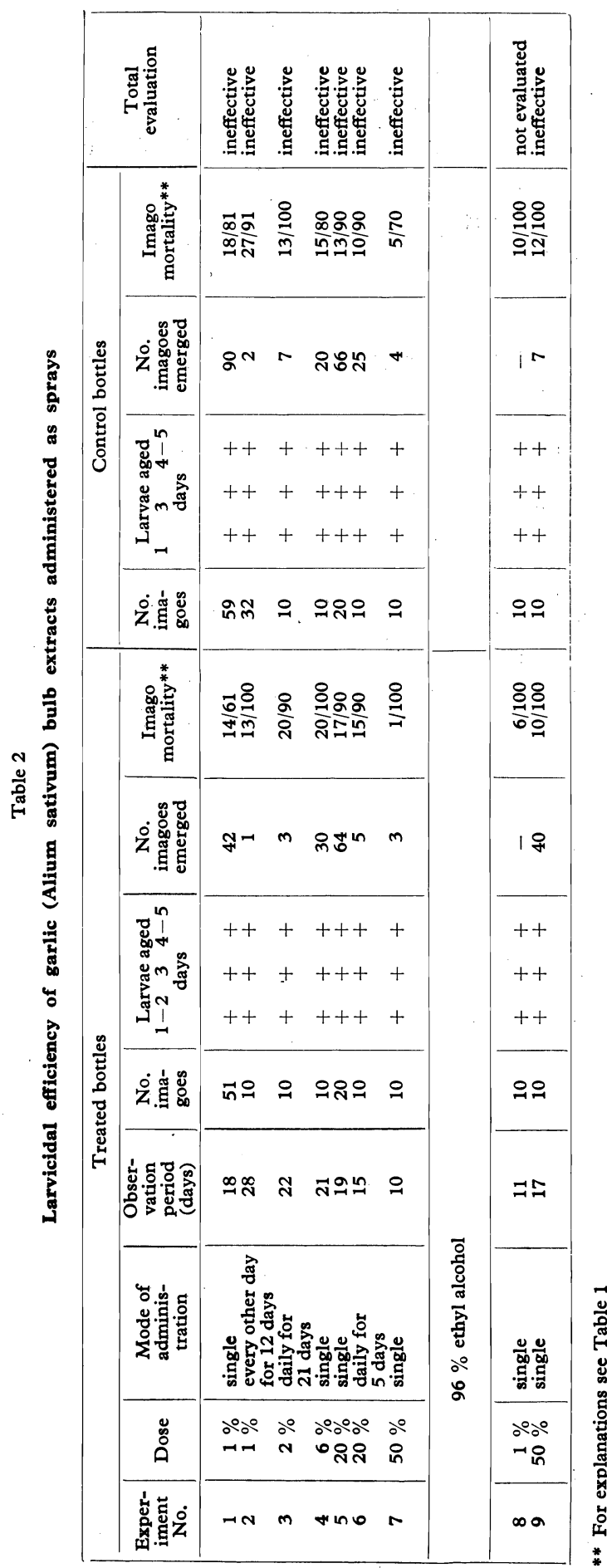




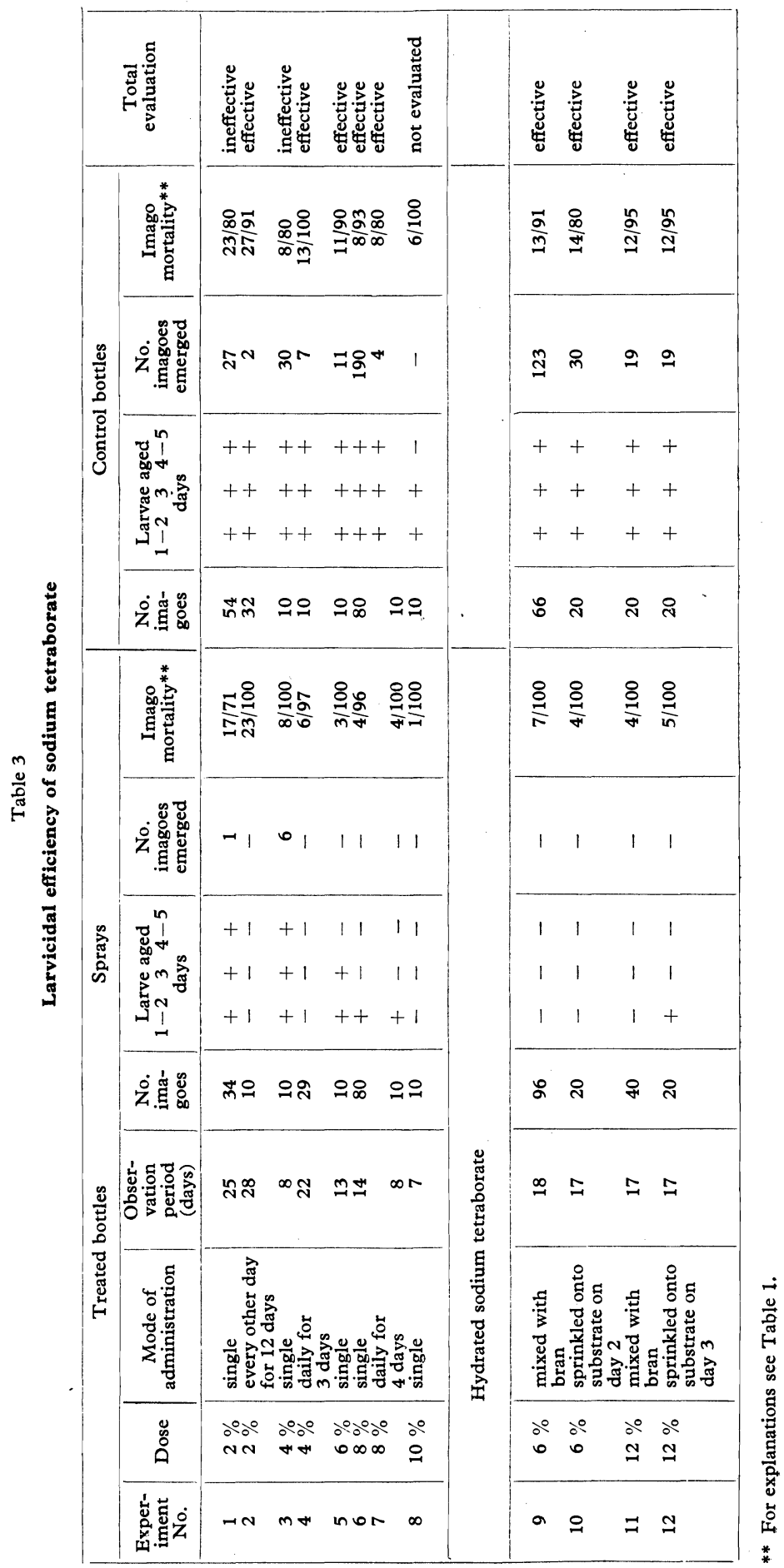


and 7). A fairly high degree of larvicidal action was obtained also with hydrated sodium tetraborate mixed with wheat bran (Table 3, Experiments 9-12).

Sodium tetraborate was not toxic to guinea-pigs and experimental calves. Five treatments given to guinea-pigs produced no perceptible changes in either the skin and mouth mucosa or in the appetite of the experimental animals. Similarly sodium tetraborate-treated calves showed no changes in health status as against untreated controls during a 15-day observation period.

The cattle manure biotope sprayed with 8 per cent sodium tetraborate showed a decrease in imagoes within 5 days (Fig. 2 and 3). From the 6th day after spraying, the number of imagoes began to rise again, and on day 7 the numbers of adult flies in both the treated and control biotopes were more or less equalized.

The direct toxic effect of sodium tetraborate on house fly larvae in treated bottles was apparent for 2 to 4 days, while the residual efficiency persisted for 5 days. This is in keeping with the findings in the previous semi-operational trial where the number of imagoes in the treated biotope began to rise again on the 6th day.

\section{Discussion}

A prerequisite for laboratory testing of larvicidal agents against house fly larvae is an adequate method of house fly breeding. Otherwise it would not be possible to distinguish between the effects of test substances and the biological cycle of the house flly under experimental conditions where the development may be impaired and imagoes may die without distinct causes. Therefore it is necessary to evaluate the results in terms of larval morbidity, retardation of larval development and imago emergence from puparia.

Using the aforementioned criteria, a degree of efficiency against house flly larvae was demonstrated for the stronger of the two horse-tail decoctions that was claimed to be effective against plant-lice (Rolínková 1979). On the other hand, garlic bulb extract proved ineffective in contrast to the observations reported by Novák (1978). Great nettle extracts, which have a long-standing reputation as effective means of insect control in horticultural practice, also proved ineffective.

Our experiments with sodium tetraborate were guided by the observation of Schneider and Groth (1976) who found that it was effective to a certain degree against house fly larvae in swine manure. The advantages of sodium tetraborate are non-toxicity for warm-blooded animals as demonstrated in our experiments on guinea-pigs and calves and the fact that instead of debasing cattle manure, it enriches it with boron, a trace element, in which our soil is generally deficient. Sodium tetraborate operates mainly by affecting the metamorphosis of the house fly so that the development of puparia and, in consequence, the emergence of imagoes are significantly reduced as was demonstrated in the present study in agreement with the observations reported by Schneider and Groth (1976). Since administration of aqueous solutions of sodium tetraborate would result in increased relative humidity of the brans, hydrated sodium tetraborate mixed with sawdust or other suitable bedding material seems more convenient for practical application. This alternative has in addition the advantage of longer residual action. 


\section{Larvicidní účinnost některých látek u Musca domestica}

V laboratorních podmínkách byla ověřována účinnost síranu mědnatého, síranu železnatého, síranu hořečnatého, tetraboritanu sodného a vodného výluhu $\mathrm{z}$ rostlin kopřivy dvoudomé (Urtica dioica), přesličky rolní (Equisetum arvense), pelyňku černobýla (Artemisia vulgaris) a alkoholického extraktu česneku (Alium sativum) na larvy mouchy domácí (Musca domestica). Larvicidní účinnost byla zjištěna u $4 \%$ koncentrace síranu hořečnatého, odvaru $\mathrm{z}$ přesličky rolní a výluhu z pelyňku černobýla. Relativně vysoká účinnost byla prokázána u tetraboritanu sodného v koncentraci od 4 do $12 \%$ ve formě postřiku nebo posypu.

\section{Губительный эффект некоторых веществ у Musca domestica}

В лабораторных условиях проверялся эффект уничтожения сульфата меди, сульфата железа, сульфата магния, тетрабората натрия и водной вытяжки растений крапивы двудомной (Urtica dioica), хвоща полевого (Equisetum arvense), чернобыльника (Artemisia vulgaris) и спиртового экстракта чеснока (Alium sativum) на нимфы домашней мухи. Эффективность уничтожения была установлена у $4 \%$ концентрации сульфата магния, экстракта хвоща полевого и чернобыльника. Относительно высокая эффективность была установлена у тетрабората натрия в концентрации от 4 до $12 \%$ в форме опрыскивания или опудривания.

\section{References}

FAHR, G. - RIBBECK, R. - HIEPE, T.: Zur Fliegenbekämpfung in industriemässig produzierenden Schweineanlagen. Mh. VetMed., 32, 1977: 908-911.

KNOBLOCH, H. - RIBBECK, R. - HIEPE, T.: Untersuchungen zur Entwicklung von Musca domestica Linné, 1758, und Fannia canicularis Linné, 1761, in verschiedenen Brutsubstraten. Mh. VetMed., 32, 1977: 905-907.

NOVÁK, D.: Nově objevené účinky česneku. Zahrádkáŕ, 10, 1978: 205.

ROLÍNKOVÁ, K.: Zkušenosti s hubením mšic na rủžích odvarem přesličky rolní. Zahrádkár̆, 11, 1979: 114 .

SCHNEIDER, M. - GROTH, U.: Zur Wirkung von Insektiziden auf Larven von Musca domestica in Schweinedung. Angew. Parasit., 17, 1976: 128-141. 